\title{
Does Tourism Contribute Significantly to the Malaysian Economy? Multiplier Analysis Using I-O Technique
}

\author{
Mohammad Nurul Huda Mazumder (Corresponding author) \\ Faculty of Management, Multimedia University \\ Cyberjaya Campus, Jalan Multimedia, Cyberjaya 63100, Selangor, Malasia \\ Tel: 60-3-8312-5691_E-mail: hudametro@yahoo.co.uk \\ Elsadig Musa Ahmed \\ Faculty of Business And Law, Multimedia University \\ Melaka Campus, Jalan Ayer Keroh Lama, Melaka 75450, Malasia \\ Tel: 60-6 -252 -3807; Fax: 60-6 -231 -8869 \\ E-mail: elsadigmusa@yahoo.com, asadiq29@hotmail.com
}

\author{
Abul Quasem Al-Amin \\ LESTARI, Universiti Kebangsaan Malaysia \\ UKM Bangi 43600, Selangor, Malaysia \\ Tel: 60-3-8921-4161_E-mail: amin_cant@yahoo.com
}

\begin{abstract}
The objective of this paper is to examine the contribution made by tourism sector through deriving multipliers in terms of output, income, employment, value added, and import for the Malaysian economy using input-output techniques. Normal and ratio multipliers were measured to demonstrate the contribution made by tourism industry and its linkages with the other sectors of the economy. International tourist expenditure makes highest contribution in generating output since output multiplier is seven times higher than import multiplier. The lower value of import multiplier represents that the amount of leakage that occurs as a result of tourist expenditure is not significant. It is also evident from the results that secondary effect of tourist expenditure is found to be higher in generating output and value added. The lower value of secondary effect on income and employment suggests that tourism industry is relatively labour-intensive in nature. The multiplier analysis is found to be effective in appropriate policy making for the tourism industry. However, multiplier analysis of tourism industry of Malaysia possesses that this industry is contributing significantly to the economy and proves as a potential sector to enhance economic growth towards a developed nation by 2020 .
\end{abstract}

Keywords: Tourism, Input-output technique, Multiplier, Malaysian economy

\section{Introduction}

Malaysia is well endowed with abundance of natural resources particularly suitable for sustainable tourism. Tourism industry maintains its sustainability through its economic viability. Increasing attention has been given by the Malaysian government to develop sustainable tourism as an alternative source of foreign exchange to remedy the balance of payment deficit during 1980's. Tourist expenditure is not only contributing significantly to the direct tourism related sectors but also generating ripple effects on other sectors of the economy. Thus, tourism stimulates the economic progress of developing economies and its importance is gaining widespread recognition. Unlike many developing nations, tourism industry is now considered as one of the important engines of development for the Malaysian economy receiving vital focus in the government's industrial strategy. The development allocation for this industry has been increasing over the years. It has been increased from RM605.5 million in the $7^{\text {th }}$ Malaysian plan to RM1009.0 million in 
the $8^{\text {th }}$ Malaysian plan period, experiences $60 \%$ increase in its allocation (EPU, 2001). In the $9^{\text {th }}$ Malaysian plan period, the allocation reached to RM1367.0 million (EPU, 2006).

Tourism department officially begun in 1959 was transformed to Tourism Development Corporation (TDC) in the early 1970's, the beginning of 'new era' for the Malaysian tourism industry. The recognition also came following a phenomenal growth rate experienced by the industry since the late 1960s (Din, 1984; Wong, 1986). TDC was formed in 1972 under the Ministry of Trade and Industry (MITI), which was responsible for the coordination, development, and promotion of domestic and international tourism (Din, 1984; Wong, 1986). During the period of 1970s, government efforts to develop tourism was set off to several development objectives such as, increasing foreign exchange earnings, increasing employment, and income levels, fostering regional development, diversifying the economic base, and increasing government revenue (Khalifah and Tahir, 1997). The concentrated effort was given to the development of basic infrastructure for tourism in that period. Tourism industry accrued higher priority from the government in 1980s when traditional export sectors faced a decline in their performance due to global recession. Government supports for tourism continued with the establishment of the Ministry of Tourism and Culture in 1987 later renamed as the Ministry of Culture, Arts, and Tourism (MOCAT) in 1990. The industry has had full support in terms of funding, planning, coordination, regulation and enforcement (Musa, 2000) with formation of MOCAT which was upgraded to the Ministry of tourism in 2004 to coordinate, direct, and ensure that all tourism development initiatives and programs were implemented according to National Tourism Master Plan in line with the government's objective to encourage and accelerate the domestic private sector and stimulate the tourism sector to lead the growth of the economy.

The industry not only creates considerable high multiplier effects and linkages in the economy, but also fosters national integration and unity" (GOM, 1991). If this trend of tourism growth in Malaysia continues, it may surpass manufacturing sector, which, since 1987 has been the country's engine of growth. The revenue earned from international tourism has a pivotal role that directing Malaysian economy to higher growth (Sadi and Bartels, 1997).

Malaysian economy's current account balance remains relatively resilient with manufacturing and tourism taking the lead. Tourism industry is currently the second largest foreign exchange earner, after manufacturing. Tourism receipts increase significantly over the last three decades. Increase in tourism receipts in 1982-2007 periods was about 42 folds on an average of 12.42 per cent annually with an average annual growth of 17.58 per cent. Tourism receipts increase with the increase in tourist arrivals. For instance, tourists' arrivals have increased from 2.7 million in 1982 to 13.3 million in 2002, and to 20.97 million in 2007 with an average annual growth rate of 10.17 per cent (Figure 1).

In the service account of the balance of payments, the share of tourism revenue in total earnings increased from 32.7 percent in 2000 to 43.0 percent in 2005. According to Economic Report 2007/2008, gross tourism earnings have increased to RM38.2 billion in 2006, responsible for 6.7 per cent of nominal GDP. During 2003-2007 periods, tourism industry contribution to GDP has increased from $5.6 \%$ to $7.4 \%$. Furthermore, this industry also plays a pivotal role in increasing the living standard of low-income groups.

Malaysia is on the verge of a tourism boom and tourism industry contributes to socio-economic development and quality of life. Tourism and hotel industry in Malaysia showed an upward trend until the onset of financial crisis in 1997, SARS and the US-Iraq war in 2003 (Poon and Low, 2005). Within these world consequences, tourism sector was not that jeopardised like other sectors of the Malaysian economy. It can be envisaged that this industry will continue to be a major source of growth and a key driver in the development of services sector during the $9^{\text {th }}$ Malaysia Plan period (2006-2010). The tourism industry has come a long way since its inception in 1959 with only a Tourism Department back then. Today, half of a century later, the industry has reached to such a magnitude to become the second highest foreign exchange earner to the national economy experiencing tremendous growth from year to year (Figure 1).

This paper hopes to gain more current and applicable information about the economic contribution of international tourism through estimating tourism multipliers for the Malaysian economy, to strengthen the basis for making informed decisions concerning tourism development. A better understanding of the economic contribution of tourism can be achieved by examining the tourist industry in terms of income, output, employment, value added and import multipliers that will assist policy makers in appropriate planning.

The initial injection of tourist expenditure has direct, indirect (production induced), and induced (consumption induced) impacts on the local economy. This process of multiplier effect of tourist expenditure continues until money goes out of the circulation in the form of leakages through savings, taxes, and imports. This ripple effect in an economy is termed the 'tourism multiplier' (Wanhill, 1994). Therefore, estimating tourism multipliers will provide insights about the contribution made by different sectors of the tourism industry in the Malaysian economy. In tourism economics, examination of the economic impact has usually been based on multipliers derived from input-output (I-O) analysis (Sinclair, 1998; Wagner, 1997). The measurement of multipliers (output, income, employment, value-added and import) shows the effect of a unit increase in tourism expenditure on other production sectors of an economy. With the expansion of tourism, which sector demand more inputs or factors of production from other sectors and magnitude of 
these changes can be illustrated by estimating tourism multipliers. In estimating tourism multipliers this paper uses input-output technique that perhaps measure the significance of tourism industry for the Malaysian economy.

\section{Literature review}

Development of tourism multipliers using input-output technique carried out by researchers drawn an attention only after 1960's with one of the prominent literature in estimating the economic impact of tourism in Missouri state economy was carried out by Harmston (1969). Since then, estimation of economic significance of tourism industry is playing a vital role in tourism economics. Most importantly, the determination of multipliers of tourist expenditure was the major concern constituted one of the most researched issues (Sinclair, 1998). Estimation of the multipliers of tourism was conducted by researchers at state or county level (Bryden, 1973; Archer, Shea and Vane, 1974; Armstrong, Daniel and Francis, 1974; Liu and Var, 1983; Liu, 1986; Fasenmaier et.al., 1989; Teisl and Reiling, 1990; Vilaplana, Pai and Hushak, 1991; Archer, 1995; Andrew, 1997; Martin, 2004) and nation-wide level (Diamond, 1976; Archer, 1985; Ruiz, 1985; Heng and Low, 1990; Khan, Seng, and Cheong, 1990; Kweka, Morrissey, and Blake, 2001; Durbarry, 2002; Crespo and Diaz, 1997; Khan, Phang, and Toh, 1996; Tohamy, 2001). Most of the previous empirical studies adopted input-output technique to evaluate the total economic impact of tourist expenditure and concentrated on estimating multiplier values of tourism for different countries using input-output analysis. The previous empirical studies emphasized on estimating output and income multipliers only. Kweka et.al. (2003) measured the economic potential of tourism in Tanzanian economy using input-output technique. The major drawbacks of their analysis are they only represent the direct and indirect effect of tourism. Another drawback of their exercise is that they only consider hotel and restaurant sector as the only tourism related sector. One of most recent study was conducted by Rashid and Bashir (2004) on the Malaysian tourism industry using primary input partial multipliers. The principle weakness of input partial multiplier is that it does not consider household sector in estimating induced effect, thus their study failed to analyse income and employment effect accurately. Therefore, this study considers the direct, indirect, and induced multiplier effects to overcome the shortcomings of Rashid and Bashir (2004) study, where household consumption and income vectors are included in the Leontief matrix.

This paper is organized according to the following details. Section 1 describes the background of tourism in Malaysia, followed by summary of the previous studies are evident in section 2. Input-output techniques is used to determine the direct, indirect, and induced multiplier effects of tourists expenditure in terms of output, income, employment, value-added, and import were outlined in section 3. Section 4 is devoted to results and discussions. In section 5, some policy implications are addressed with conclusion.

\section{Methodology}

There are a number of methodologies developed to determine the multipliers. The most widely used approach is the input-output technique. The major strength of input-output analysis is that it provides detailed information on direct, indirect and induced effects of visitor spending on all economic measures for different industries in the local economy (Loomis and Walsh, 1997). Therefore, in order to satisfy the aforementioned objectives, the methodology employed in this paper is based on Leontief input-output techniques where structure of an economy is analyzed in terms of inter-relationships between economic sectors (e.g. Miller and Blair, 1985). The input-output technique of a particular economy represents the flow of goods and services among its different industries for a particular time period. In the framework of input-output technique, the relationships between economic sectors can be described in a system of linear equations where total output produced by each sector is either consumed as an intermediate input by other sector, or, sometimes internally by the producing sector itself, or, by the final demand sector, or both. The presentation of the flow of goods and services could be expressed either by physical units or in money terms. To define, let there be an economy with n-producing sectors and a final demand sector. Total output of sector $i$ will be:

$$
\mathrm{X}_{i}=\sum_{\mathrm{j}=1}^{\mathrm{n}} \mathrm{x}_{i j}+\mathrm{F}_{i}
$$

where, $\mathrm{X}_{i}=$ gross output of sector $\mathrm{i} ; \mathrm{X} i j=$ the sales of sector $\mathrm{i}$ to sector $\mathrm{j} ; \mathrm{F}=$ the final demand vector; $\mathrm{i}=1, \ldots \ldots \ldots, \mathrm{n}$

Let $a_{i j}$ be the technical (input) coefficient which represents the amount (value) of sector i's output needed to produce one unit (one Ringgit) of sector j's output; thus, using the assumption of constant production coefficient, we get:

$$
\mathrm{a}_{i j}=\mathrm{x}_{i j} / \mathrm{X}_{j} \quad \text { or } \quad \mathrm{x}_{\mathrm{ij}}=\mathrm{a}_{i j} \mathrm{X}_{j}
$$

Which means that the total value of purchases of goods and services by sector $\mathrm{j}$ from sector $\mathrm{i}$ is $\mathrm{a}_{\mathrm{ij}} \mathrm{X}_{\mathrm{j}}$.

Therefore, for a given target of final demand on goods and services, $\mathrm{F}$, this relation defines how much each producing sector must produce in order to satisfy a particular bundle of final demand on goods and services, i.e., Equation (1) in reduced matrix form can be written as: 


$$
\mathrm{X}=\mathrm{AX}+\mathrm{F}
$$

Solving the equation (2) can be found as:

$$
\mathrm{X}=[\mathrm{I}-\mathrm{A}]^{-1} \mathrm{~F}
$$

In Equation (3), $\mathrm{X}$ is the output vector; $\mathrm{I}$ is an identity matrix and $[\mathrm{I}-\mathrm{A}]^{-1}$ is the total requirement matrix or mostly known as the Leontief inverse matrix.

The general solution of Equation (3) determines how much each sector of the economy must produce in order to satisfy a given level of final demand. It is mandatory that $[\mathrm{I}-\mathrm{A}]$ should be a non-singular matrix meaning that the determinant of $[\mathrm{I}-\mathrm{A}]$ does not equal to zero to have a unique solution in the form of $[\mathrm{I}-\mathrm{A}]^{-1}$. When the Leontief inverse matrix is assumed to be $[\mathrm{I}-\mathrm{A}]^{-1}=\mathrm{Z}$, then $z_{i j}{ }^{\prime}$ s stand for the elements of the Leontief inverse matrix. Each element of the $[\mathrm{I}-\mathrm{A}]^{-1}$ shows the direct and indirect requirements of output of sector i per unit of final demand.

\section{Multiplier Analysis}

Central to any analysis related to measure the contribution of an activity are economic multipliers, which are derived from the inverse coefficients or total requirements table. In developing multipliers related to tourism sectors in the Malaysian economy, the following procedures are followed. First, Malaysian input-output transaction table is aggregated to 52 sectors. Followed by, the construction of direct requirements matrix. Then, direct and indirect requirement matrixes construction is done. In step four, we develop the direct, indirect, and induced requirement matrix. Tourism multipliers are derived in step five.

The 94X94 sectors of Malaysian economy transactions table has been aggregated into 52X52 sectors. Average expenditure patterns of tourist have been allocated to the relevant industrial input-output categories taken from 52X52 sectors. This means that the input-output transactions table that has been considered in this study includes: (1) fifty two processing sectors; (2) six final demand sectors; and (3) five payment sectors. Since leakages are substitutes for domestic production, the input-output technique has been modified in this analysis reflects the import leakages as:

Where,

$$
\mathrm{X}_{52 \mathrm{X} 1}=\mathrm{A}_{52 \mathrm{X} 52}^{\mathrm{d}} * \mathrm{X}_{52 \mathrm{X} 52}+\mathrm{F}_{52 \mathrm{X} 1}-\mathrm{IM}_{52 \mathrm{X} 1}
$$

$\mathrm{X}_{52 \mathrm{X} 1}=$ the vector of gross output produced by each of 52 sectors for the Malaysian economy,

$\mathrm{A}_{52 \times 52}^{\mathrm{d}}=$ the direct requirements (input coefficients) matrix for 52 sectors, which represents domestic production,

$\mathrm{X}_{52 \times 52}=$ the diagonal matrix with each of 52 sectors gross output on the diagonal,

$\mathrm{F}_{52 \times 1}=$ the vector of final demand sold by 52 sectors,

$\mathrm{IM}_{52 \mathrm{X} 1}=$ the vector of imports made by 52 sectors.

The matrix of input coefficients, " $\mathrm{A}_{52 \times 52}^{\mathrm{d}}$ " represents only the direct effects of any change in tourist expenditure. To reflect the direct and indirect effects, the matrix of input coefficients must be subtracted from an identity matrix and then, the results are inverted as:

$$
\mathrm{X}_{52 \mathrm{X} 1}=\left(\mathrm{I}_{52 \mathrm{X} 52}-\mathrm{A}_{52 \times 52}^{\mathrm{d}}\right)^{-1}\left(\mathrm{~F}_{52 \mathrm{X} 1}-\mathrm{IM}_{52 \mathrm{X} 1}\right)
$$

Where,

$\mathrm{I}_{52 \times 52}=$ a $52 \mathrm{X} 52$ identity matrix,

$\mathrm{X}_{52 \mathrm{X} 1}, \mathrm{~A}_{52 \mathrm{X} 52}^{\mathrm{d}}, \mathrm{F}_{52 \mathrm{X} 1}$, and $\mathrm{IM}_{52 \mathrm{X} 1}=$ as per equation (1),

$\left(\mathrm{I}_{52 \times 52}-\mathrm{A}_{52 \times 52}^{\mathrm{d}}\right)^{-1}=$ the direct and indirect requirements matrix for 52 sectors.

Tourist expenditure generates income for the economy. According to Keynes, if a certain amount of income due to an exogenous expenditure were injected into an economy, consumer spending would increase by less than the injection of income (Miernyk, 1965). In the same way, Archer (1982) also revealed that an increase in household income (wages and salaries) resulting from tourist spending would lead to a rise in household consumption. This increase in household consumption provides further impetus to the economic activity, such as income, employment and business turnover. This is known as induced effect of tourist spending.

Therefore, this study expanded the input-output technique through the inclusion of the household sector as one of the processing sectors. Because of the inequality between the sum of compensation of employee and the sum of private consumption in the Malaysian input-output transaction table, it is necessary to make a reconciliation of the household row and the column totals by adjusting some of the other entries in the payment and final demand sectors (Miernyk, 1965).

Once this adjustment has been made, the new matrix of technical coefficients yields a new Leontief inverse matrix as 


$$
\mathrm{X}_{53 \mathrm{X} 1}=\left(\mathrm{I}_{53 \times 53}-\mathrm{A}_{53 \mathrm{X} 53}^{\mathrm{d}}\right)^{-1}\left(\mathrm{~F}_{53 \mathrm{X} 1}-\mathrm{IM}_{53 \mathrm{X} 1}\right)
$$

Where,

$\mathrm{X}_{53 \mathrm{X} 1}=$ the vector of gross output produced by each of 53 sectors including the household sector,

$\mathrm{A}^{\mathrm{d}}{ }_{53 \times 53}=$ the new direct requirements matrix for 53 sectors including the household sector,

$\mathrm{F}_{53 \mathrm{X} 1}=$ the vector of final demand sold by 53 sectors,

$\mathrm{IM}_{53 \mathrm{XX}}=$ the vector of imports made by 53 sectors.

$\left(\mathrm{I}_{53 \times 53}-\mathrm{A}_{53 \times 53}^{\mathrm{d}}\right)^{-1}=$ the direct + indirect + induced requirements matrix with being the household sector endogenous.

One of the most powerful mathematical analytical tool named MATLAB has been used to compute the new Leontief inverse matrix, $\left(\mathrm{I}_{53 \times 53}-\mathrm{A}_{53 \times 53}^{\mathrm{d}}\right)^{-1}$ which would measure the direct, indirect, and induced effects of any change in tourist expenditures in the Malaysian economy. Once the direct, indirect, and induced requirements matrix has been estimated, the output, income, employment, value-added, and import multipliers can be derived for each of six tourism sectors. The output multiplier shows how much one additional unit of tourist spending increases the level of output in the Malaysian economy. By denoting the direct, indirect, and induced requirements matrix of $\left(\mathrm{I}-\mathrm{A}^{\mathrm{d}}\right)^{-1}$ as " $\mathrm{M}$ ", the output multipliers for each of six tourism sectors can be calculated as:

Where,

$$
\mathrm{O}_{1 \times 6}=\mathrm{i}_{1 \times 6} * \mathrm{M}_{6 \times 6}
$$

$\mathrm{O}_{1 \times 6}=$ the vector of output multipliers for six tourism sectors in the Malaysian economy,

$\mathrm{i}_{1 \mathrm{X} 6}=$ the (final demand) vector of six tourism sectors,

$\mathrm{M}_{6 \mathrm{X} 6}=$ the direct + indirect + induced requirements matrix for six tourism sectors.

The income multiplier for a particular tourism sector measures the change in household income for that sector resulting from one additional unit change in tourist spending. The income multiplier for each of six tourism sectors can be estimated as:

Where,

$$
\mathrm{E}_{1 \mathrm{X} 6}=\left(\mathrm{H}_{1 \mathrm{X} 6} / \mathrm{X}_{1 \mathrm{X} 6}\right) * \mathrm{M}_{6 \mathrm{X} 6}
$$

$\mathrm{E}_{1 \mathrm{X} 6}=$ the vector of income multipliers for six tourism sectors in the Malaysian economy,

$\mathrm{H}_{1 \times 6}=$ the vector of household income for six tourism sectors expressed in millions of Ringgit,

$\mathrm{X}_{1 \mathrm{X} 6}=$ the vector of gross output for six tourism sectors expressed in millions of Malaysian Ringgit,

$\left(\mathrm{H}_{1 \times 6} / \mathrm{X}_{1 \mathrm{X} 6}\right)=$ the vector of direct income effects for six tourism sectors,

$\mathrm{M}_{6 \mathrm{X} 6}=$ as per equation (7).

The employment multiplier for a particular tourism sector measures the number of jobs generated for that sector as a result of one additional unit of tourist expenditures. The employment multiplier for each of six tourism sectors can be computed as:

$$
\mathrm{L}_{1 \times 6}=\left(\mathrm{E}_{1 \mathrm{X} 6} / \mathrm{X}_{1 \mathrm{X} 6}\right) * \mathrm{M}_{6 \mathrm{X} 6}
$$

Where,

$\mathrm{L}_{1 \times 6}=$ the vector of employment multipliers for six tourism sectors in the Malaysian economy,

$\mathrm{E}_{1 \mathrm{X} 6}=$ the vector of paid employees for six tourism sectors expressed in millions of Ringgit,

$\mathrm{X}_{1 \mathrm{X} 6}=$ the vector of gross output for six tourism sectors expressed in millions of Malaysian Ringgit,

$\left(\mathrm{E}_{1 \mathrm{X} 6} / \mathrm{X}_{1 \times 6}\right)=$ the vector of direct employment effects for six tourism sectors,

$\mathrm{M}_{6 \mathrm{X} 6}=$ as per equation (7).

The value-added multiplier for a particular tourism sector measures the change in value-added for that sector resulting from one additional unit change in tourist spending. The value-added multiplier for each of six tourism sectors can be estimated as:

Where,

$$
\mathrm{VA}_{1 \mathrm{X} 6}=\left(\mathrm{V}_{1 \times 6} / \mathrm{X}_{1 \mathrm{X} 6}\right)^{*} \mathrm{M}_{6 \mathrm{X} 6}
$$

$\mathrm{VA}_{1 \times 6}=$ the vector of value-added multipliers for six tourism sectors in the Malaysian economy, 
$\mathrm{V}_{1 \mathrm{X} 6}=$ the vector of value-added for six tourism sectors expressed in man-years,

$\mathrm{X}_{1 \mathrm{X} 6}=$ the vector of gross output for six tourism sectors expressed in millions of Malaysian Ringgit,

$\left(\mathrm{V}_{1 \times 6} / \mathrm{X}_{1 \times 6}\right)=$ the vector of direct value-added effects for six tourism sectors,

$\mathrm{M}_{6 \mathrm{X} 6}=$ as per equation (7)

The import multipliers for a particular tourism sector measures the change in import for that sector resulting from one additional unit change in tourist spending. The import multiplier for each of six tourism sectors can be estimated as:

Where,

$$
\mathrm{S}_{1 \mathrm{X} 6}=\left(\mathrm{IM}_{1 \mathrm{X} 6} / \mathrm{X}_{1 \mathrm{X} 6}\right) * \mathrm{M}_{6 \mathrm{X} 6}
$$

$\mathrm{S}_{1 \mathrm{X} 6}=$ the vector of import multipliers for six tourism sectors in the Malaysian economy,

$\mathrm{IM}_{1 \mathrm{X} 6}=$ the vector of import for six tourism sectors expressed in millions of Ringgit,

$\mathrm{X}_{1 \mathrm{X} 6}=$ the vector of gross output for six tourism sectors expressed in millions of Malaysian Ringgit,

$\left(\mathrm{IM}_{1 \mathrm{X} 6} / \mathrm{X}_{1 \mathrm{XX}}\right)=$ the vector of direct import effects for six tourism sectors,

$\mathrm{M}_{6 \mathrm{X} 6}=$ as per equation (7).

\section{Description of Data Collection}

Tourism industry is not classified as single industry according to SIC code of Malaysia. This industry is formed by aggregating different economic activities that serve it directly. In order to determine tourism multipliers through input-output techniques, the Year 2000 Malaysian national input-output transaction table (the latest table published by department of statistics in the year of 2005) has been utilized. Sectoral gross output and household income for 2000 were obtained from the 2000 Input-Output transaction table. The number of paid employees' for the year 2000 was derived from considering compensation of employees' row of the 2000 Input-Output transaction table. Apparently, Import and value added data have been taken from the 2000 Malaysian Input-Output transaction table. The 2000 Input-Output tables are a 94 X 94 sector Input-Output matrix of Malaysia. In this study, the 94 sectors in a transaction table are aggregated into 52 sectors and focus given to tourism-related sectors. Next, this transaction table is constructed into a technical coefficient matrix in order to conduct further analysis. Then, coefficient table is developed to derive multipliers. The aggregating process follows the guideline of Handbook of Input- Output Table Compilation and Analysis, UN, New York, 1999 (UN, 1999). Additional information and data was collected from Malaysian Tourism Promotion Board (MTPB).

\section{Results and Discussion}

This section represents contributions made by tourism sector. The multipliers are derived in terms of output, income, employment, value-added and import in the Malaysian economy. According to the research objectives, this study uses Input-Output technique to derive multipliers for the tourism industry.

\subsection{Average Tourism Multipliers}

(Table 1) shows the estimates of the average output multipliers on the Malaysian economy where both normal and ratio multipliers are evident.

The average tourism output multiplier illustrates that every Ringgit increase in the tourist expenditure would generate 1.42 Ringgit. The direct, indirect and induced effects that attributed to the total on average effect are $0.22,1.14$ and 0.07 respectively. The large figure or proportion of the indirect effect indicates the importance of the secondary effect. The relatively high Type I (6.26) and Type II (6.56) multipliers indicates relatively strong linkages with all sectors of the economy which is analogous to the secondary effect of tourism reflecting the significance of the secondary impact of tourism.

Accordingly, tourism average income multiplier shows the creation of local incomes in the form of salaries, wages, profits, rents, and interest at direct, indirect and induced levels, as a result of tourist expenditure. The average income multiplier of tourism that is represented in (Table 1) indicates that for every Ringgit of tourist spending generates 0.35 Ringgit of household income to the Malaysian residents. Out of 0.35 income multiplier of tourism on average, 0.27 Ringgit contributed by direct income effect, the indirect income effect is responsible for generating 0.07 Ringgit of income, and 0.01 Ringgit is contributed by induced income effect in the Malaysian economy. The secondary income effect of the tourism industry (0.07) is relatively not that much larger than the primary income effect $(0.27)$ compared to output effect in which secondary output effect was about 6 times larger than primary output effect (0.22). Analysis of comparison between secondary and primary effect of income suggests that tourism industry is relatively high wage intensive in nature. This can be observed from relatively low Type I (1.24) and Type II (1.29) income multipliers. 
Tourism average employment multiplier measures the average number of employment generated for a given unit of tourist expenditure. the on average tourism employment multiplier (Table 1) is found to be 0.174 per one million Ringgit of the tourism sector's output, meaning that a total of 174 full-time employments have been generated by tourism for every billion Ringgit of tourist expenditure. Of the total of 174 full-time employments, the direct employment effect attributes 125 employments, 40 employments are contributed by indirect employment effect and induced employment effect generates 9 employments. The smaller number of indirect and induced employment effects signify the less importance of secondary effect in generating employment when compared with direct employment effect. The relatively low Type I (1.32) and Type II (1.39) results representing the apparent outcome.

Likewise, average amount of local income that a specific tourism sector generates in the Malaysian economy in the form of salaries and wages, surpluses by business operation, and depreciation or consumption of fixed capital, resulting from one Ringgit increase in tourist expenditure can be explained by value-added multipliers of tourism. The on average value-added multiplier of tourism reflects that every Ringgit of tourist spending approximately contributes 0.56 Ringgit of income to the resident economy. Out of this 0.39 Ringgit is generated by direct value-added effect, indirect value-added effect generates 0.14 Ringgit to the local economy and 0.03 Ringgit is the amount of local income that has been generated by induced value-added effect.

The import multiplier of tourism in the Malaysian economy symbolizes the proportion of one Ringgit of exogenous tourism expenditure needed to import in order to produce one Ringgit worth of the output for a particular tourism sector. In other words, the amount of leakages from the economy per Ringgit of tourist expenditure is measured by the import multiplier. As presented in (Table 1), the on average tourism import multiplier implies that approximately 0.22 Ringgit is leaking out from the Malaysian economy for one Ringgit of expenditure of tourists.

\subsection{Output Multiplier}

The output multipliers of the Malaysian tourism industry of each of the six tourism sectors are represented in (Table 2) including normal and ratio multipliers. Among the tourism related sectors, the food and Beverage sector yields the largest output multiplier with multiplier of 1.82. Of the total output multiplier generated by tourism, the corresponding contribution of direct, indirect and induced effects are $0.43,1.26$ and 0.04 Ringgit respectively. The accommodation sector constitutes the second most important output generating sector with the multiplier of 1.44 . Of this multiplier, 0.22 Ringgit created by direct effect, 1.16 Ringgit by indirect effect and 0.05 Ringgit by induced effect. Tour and transportation sector is the third most important sector generated the multiplier of 1.41. The other remaining tourism sectors, such as miscellaneous services (1.36), entertainment (1.28), and shopping sector (1.20) retained low output multipliers with less than a tourism industry average of 1.42. The shopping sector yields the largest Type I and Type II multipliers which are greater than the industry average of 6.26 and 6.56 respectively, reflecting the high degree of interdependence with all sectors in the economy. Among the obtained multipliers, it is noticeable that the sectors that generate high normal multipliers yield low ratio multipliers which are even lower than industry average. Such as, regardless of high normal multipliers, the sector of Food and Beverage yields low ratio multipliers of Type I (4.17) and Type II (4.27) that imply that this sector has relatively weak linkages with other sectors of the economy. The sector of Tour and Transport yields the second lowest ratio multiplier of Type I (5.56) and Type II (5.80) whereas accommodation sector generates the third lowest ratio multiplier of 6.27 and 6.51 for Type I and Type II respectively.

\subsection{Income Multiplier}

Income multiplier estimates the amount of local income that has been generated as a result one Ringgit injection of tourist expenditure in the form of salaries, wages, profits, rents, and interest at direct, indirect and induced levels. According to our findings i.e., (Table 3), the entertainment sector is found to be the most important income generating sector with highest income multiplier of 0.72 . The second most important sector is the accommodation sector in terms of income generation which is holding the income multiplier of 0.66 . The tourism income multipliers for these two sectors are greater than the industry average of tourism (0.35). Among the tourism related sectors, the food and beverage sector and tour and transport sector have been secured the third and fourth position respectively, generating 0.29 Ringgit and 0.19 Ringgit of household income per Ringgit of tourist expenditure, respectively. The miscellaneous sector remains last while the shopping sector retains fifth in terms of income generation. The income multiplier for miscellaneous service sector is 7 times smaller than that of entertainment sector. Though miscellaneous sector obtained lowest normal multiplier, this sector has the highest Type I (2.48) and Type II (3.59) income ratio multipliers. Contrary to the fact that while the entertainment sector is the most important income generating sector in terms of normal multiplier, this sector has the lowest Type I (1.09) and Type II (1.11) ratio multipliers.

It can be conclude that multipliers gathered from normal and ratio approaches tend to have opposite directions and patterns. Such as, it has been noticed that the entertainment sector has been found to be the second lowest Type I (1.09) and Type II (1.11) ratio multipliers while this sector was the second most important sector in terms of normal income multiplier. These paradoxical patterns were found in the study of Gwynedd by Archer et al. (1974) and in the study of Turkey by Liu et al. (1984). 


\subsection{Employment Multiplier}

The number of employment generated for a given unit of tourist expenditure can be estimated by employment multiplier. The indirect employment effect represents the additional employment resulted from production effect and the induced employment effect describes the induced number of employment created resulting from household consumption. According to our findings in (Table 4), the highest employment multiplier of 0.21 has been retained by the tour and transportation sector. The second highest important sector in generating employment is the shopping sector with a multiplier of 0.20 followed by the accommodation sector with employment multiplier of 0.17 . The entertainment sector, miscellaneous services sector and food and beverage sector ranked fourth, fifth and sixth in terms of employment multiplier.

The employment multiplier for tour and transport sector is higher than the industry average and about two times bigger than food and beverage sector. Thus indicating that the propensity to generate employment is high by this sector compared to other tourism sectors. This also explains that the tour and transport business is more labour-intensive than any other sector of the tourism industry. When ratio multipliers are taken into consideration, the food and beverage sector with lower normal multiplier has relatively strong linkages with the rest of the sectors of the economy. While tour and transportation sector retains the highest normal multiplier, it has relatively low ratio multipliers. It is also evident that the shopping sector with second highest normal multiplier has relatively weak linkages. Similar to the results found for the output and income multiplier, contrary results between normal and ratio multipliers are also apparent in employment multiplier analysis.

\subsection{Value-Added Multiplier}

The Ringgit amount of value that has been added in the form of salaries and wages, surpluses, and consumption of fixed capital on a particular product due to a one unit increase in tourism expenditure is estimated by calculating value added multipliers. The largest value-added multiplier of 0.78 is generated by the shopping sector, followed by entertainment sector with value-added multiplier of 0.74 (Table 5).

The tour and transportation sector and accommodation sector are appeared to be the third and fourth most important sector in regard to the generation of local income. Nevertheless, the miscellaneous services sector has emerged as the least important sector in the generation of local income. Relatively small increase in the value of indirect effect and induced effect compared to the direct effect reflects the less importance of the secondary effect. The contribution of shopping sector is significant in generating value-added lying above the industry average and more than three times bigger than miscellaneous service sector. Though the normal value-added multiplier of shopping sector (0.78) is the highest among the sector, the ratio multiplier is the lowest generating type I ratio multiplier of 1.21 and type II ratio multiplier of 1.29 respectively in compared to other sectors that suggest that this sector has relatively weak linkages with the other sectors of the economy in generating local income. Whereas value-added multiplier of miscellaneous services sector yields the lowest normal value added multiplier of 0.31 but yields the highest ratio multiplier of Type I (1.18) and Type II (1.29) (Table 5). This reverse nature of multipliers is analogous to the previously illustrated multipliers.

\subsection{Import Multiplier}

Import multiplier (Table 6) represents the amount of tourist expenditure leaking out of the economy to pay for the direct, indirect and induced imports of goods and services required to satisfy tourist consumption. The lower the import multiplier, the less tourism receipts will leak out from the economy. With a multiplier of 0.09 , the entertainment sector generates the lowest import multiplier where as the tour and transportation sector produces the highest import multiplier of 0.33 . The multiplier of 0.16 has been attributed by the shopping sector which maintains the second lowest import multiplier while the accommodation sector has the second highest import multiplier.

The results show that the tourism sectors with relatively larger value-added multiplier have relatively smaller import multipliers when comparing import multiplier with the value-added multiplier. For instance, the shopping sector has the propensity to generate a large value added multipliers and relatively small import multipliers, whereas the tour and transportation sector has the propensity to generate relatively small value-added with largest import multiplier.

\section{Conclusion and Policy Implication}

This paper quantified the multipliers of the tourism industry for the Malaysian economy using input-output technique. The faster growth of the sectoral contribution of Malaysian tourism industry and its contribution in generating output, income, employment, value-added, and import is significant. As the economic importance of tourism industry is growing among the policy makers and researchers, this study applied input-output technique to determine multipliers to gauge the significance of tourism in generating output, income, employment, value-added, and import. The obtained average tourism multipliers and sectoral (tourism-related) multipliers reveal several interpretations, first, Malaysian tourism industry not only playing an important role for generating output, income, employment, value-added, and import but also creates spill over effects on other tourism related sectors of the economy. This industry has strong 
inter-sectoral linkages with other sectors of the economy. Secondly, results that have been estimated in this study can be considered as a guideline to the tourism industry policy makers to take necessary actions in developing and implementing policies and then to pay attention to promote those areas of tourism where direct, indirect, and induced effect is highest. Multiplier analysis, however, is the best element in policy making that must be taken into account before decisions are made.

According to the results, average tourism output multiplier found in this study represents the direct, indirect and induced effects that attributed to the total are $0.22,1.14$ and 0.07 respectively. The relatively high Type I (6.26) and Type II (6.56) output multipliers reveals that this industry has relatively strong linkages with all sectors of the economy. Furthermore, the average income multiplier of tourist expenditure generates 0.35 Ringgit of household income to the Malaysian residents, of which 0.27 Ringgit contributed by direct income effect, the indirect income effect is responsible for generating 0.07 Ringgit of income, and 0.01 Ringgit is contributed by induced income effect in the Malaysian economy. In addition to this, the on average tourism employment multiplier is found to be 0.174 per one million Ringgit of the tourism sector's output from which a total of 174 full-time employments have been generated by tourism for every billion Ringgit of tourist expenditure.

The results show that the distribution of tourist expenditure is unequal in generating output, income, employment, value-added and import. The highest contribution of tourist expenditure is found for the generation of output since output multiplier is seven times higher than import multiplier. The lowest value of import multiplier is meaning that the amount of leakages that occurs as a result of tourist expenditure is not significant. In other words, tourism industry is less dependent on foreign goods and services in satisfying tourist consumption. It is also evident from the results that secondary effect of tourist expenditure is found to be higher in generating output and value added. The lower value of secondary effect on income and employment suggests that tourism industry is relatively labour-intensive in nature. Analysis of comparison between secondary and primary effect of income suggests that tourism industry is relatively high wage intensive in nature. This can be observed from relatively low Type I (1.24 and 1.32)) and Type II (1.29 and 1.39) income and employment ratio multipliers consecutively. It can be observed from the results that the pattern and nature of normal and ratio multipliers are found different. When concern is given to tourism planning and development, these paradoxical results of normal and ratio multipliers distort policy makers in applying tools for appropriate policy initiatives. The support for the normal view on multipliers is pertinently to advocate that the entertainment or recreation businesses as the highest income generating sector to the residents. On the other side, the ratio approaches of multipliers are likely to suggest that miscellaneous sector is the most vital income generating sector. Since the relationships between these two approaches are remarkably opposite, Archer (1977a) noted that "They (ratio multipliers) give no indication per se of the volume of exogenous sale which are required to generate an initial unit of direct income. Without the provision of additional information relating to the creation of endogenous income to units of exogenously-derived expenditure they are valueless as a planning tool." In support to the Archer et al.'s argument, Liu et al. (1984) depict that "Normal multipliers are a better measure of overall benefit, since they provide a direct account of income generated per tourist dollar spent, while the conventional approach of using ratio multipliers gives only the extent to which secondary income generated relative to the direct income received."

The framework that has been developed in this study for the determination of multipliers and their distribution is valuable for empirical measurement that could give required guidelines to policy makers for policy making to acquire economic development through the integration of tourism development. The analysis can assist economies to enact right strategies for the development of tourism sector.

However, based on the analysis of this paper, it is obvious that tourism industry is contributing significantly to the Malaysian economy in terms of generating output, income, employment, and value-added. As Malaysia is aimed to be a developed nation by 2020 , this industry has the potential to contribute significantly towards achieving the goal.

\section{References}

Andrew, B. P. (1997). Tourism and the economic development of Cornwall. Annals of Tourism Research, 24(3), 721-735.

Anonymous. (1997b). Opening New Destinations. Asia Money. Indonesia: Emerging Opportunities Supplement.

Archer, B. H. (1995). The Impact of International Tourism on the Economy of Bermuda, 1994. Journal of Travel Research, 34(2), 27-30.

Archer, B.H. (1982). The Value of Multipliers and their Policy Implications. Tourism Management, 3(4), 236-41.

Archer, B. H. (1977a). Tourism Multipliers: The State of the Art. Bangor Occasional Papers in Economics (No.11), Bangor: University of Wales Press.

Archer, B. H. (1985). Tourism in Mauritius: An Economic Impact Study with Marketing Implications. Tourism Management, 6(1), 50-54. 
Archer, B. H., Sheila, S., \& Richard de Vane. (1974). Tourism in Gwynedd and Economic Study. Cardiff: Wales Tourist Board.

Armstrong, W.E., Daniel, S. \& Francis, A. A. (1974). A Structural Analysis of the Barbados Economy, 1968, with an Application to the Tourist Industry. Social and Economic Studies, 23(4), 493-520.

Bryden, J. M. (1973). Tourism and Development: A Case Study of the Commonwealth Caribbean. Anglia: Overseas Development Group, University of East Anglia.

Crespo, N. \& Díaz, S. N. (1997). Cuban Tourism in 2007: Economic Impact. [Online] Available: http://lanic.utexas.edu/la/cb/cuba/asce/cuba7/crespo.pdf (August 22, 2005)

Diamond, J. (1976). Tourism and Development Policy: A Quantitative Appraisal. Bulletin of Economic Research, 28(1), 36-50.

Din, K. H. (1984). Tourist Regions and Development Problems in Malaysia. Ilmu Alam 12 \& 13, 453-480

Durbarry, R. (2002). The Economic Contribution of Tourism in Mauritius. Annals of Tourism Research, 29(3), $862-865$.

Fesenmaier, D.R., Jones, L., Um, S. and Ozuna Jr, T. (1989). Assessing the economic Impact of outdoor recreation travel to the Texas gulf coast. Journal of Travel Research, 28(1), 18-23.

GOM. (1991). Sixth Malaysia Plan 1991-1995, Kuala Lumpur: Government of Malaysia.

Harmston, K. F. (1969). The Importance of 1967 Tourism to Missouri. Business and Government Review, $10(3), 5-12$.

Heng, T. M., \& Low, L. (1990). Economic Impact of Tourism in Singapore. Annals of Tourism Research, 17(2), 246-269.

Hernández, M. R. (2004). Impact of Tourism Consumption on GDP. The Role of Imports. FEEM Working Paper No. 27.2004. [Online] Available: http://papers.ssrn.com/sol3/papers.cfm?abstract_id=504505 (June 26, 2008)

Khalifah, Z. and Tahir, S. (1997). Malaysia: Tourism in Perspective. In F. Go \& C.L. Jenkins (Eds), Tourism and Economic Development in Asia and AustralasiaLondon: Cassell, pp. 177-196.

Khan, H., Phang, S. \& Toh, R.S. (1995). Singapore's Hospitality Industry: The Multiplier Effect. Cornell Hotel and Restaurant Administration Quarterly, 36(1), 64-74.

Khan, H., Chou, F. S., \& Wong, K. C. (1990). Tourism Multiplier Effects on Singapore. Annals of Tourism Research, 17(3), 408-409.

King, P. (1994, July/August). Growth Sectors, Corporate Location, ss6-ss8.

Kweka, J., Morrissey, O., \& Blake, A. (2001). Is Tourism a Key Sector in Tanzania? Input-Output Analysis of Income, Output, Employment and Tax Revenue. Christel Dehaan, Tourism and Travel Research Institute discussion paper 2001/1. [Online] Available: http://www.Nottingham.ac.uk/ttri (June 26, 2008)

Kweka, J., Morrissey, O., \& Blake, A. (2003). The Economic Potential of Tourism in Tanzania. Journal of International Development, 15, 335-351.

Liu, J. C. (1986). Relative Economic Contributions of Visitor Groups in Hawaii. Journal of Travel Research, 25(1), 2-9. Liu, J. C., \& Turgut, V. (1983). The Economic Impact of Tourism in Metropolitan Victoria, BC. Journal of Travel Research 22(2), 8-15.

Liu, J. C., Turgut V., \& Timur, A. (1984). Tourist Income Multiplier for Turkey. Tourism Management, 5(4), $280-287$.

Loomis, J.B. \& Walsh, R.G. (1997). Recreation Economic Decisions: Comparing Benefits and Costs, State College, PA: Venture Publishing Inc.

Leontief, W. (1951). The Structure of American Economy, 1919-1939. New York: Oxford University Press.

Sinclair, M. T. (1998). Tourism and economic development: A survey. Journal of Development Studies, 34 (5), 1 - 51.

Teisl, M. F. \& Reiling, S. D. (1990). Tourism and Local Government Expenditures and Revenues. The Maine Business Research Report Agricultural and Resource Economics Staff Paper. Maine: University of Maine.

Miernyk, W.H. (1965). The Elements of Input-Output Analysis. NY: Random House, Inc.

Miller, R. E. and Blair, P.D. (1985). Input-Output Analysis, Foundations and Extensions'. NJ: Prentice-Hall Inc. Englewood Cliffs.

Musa, G. (2000). Tourism in Malaysia. In C.M. Hall \& S. Page (Eds), Tourism in South and Southeast Asia: Issues and Cases. Oxford: Butterworth Heinemann, Jabatan Perhutanan Negeri Perlis. pp. 144-156. 
Poon, W. C., \& Low, K. L. T. (2005). Are Travellers Satisfied with Malaysian Hotels? International Journal of Contemporary Hospitality Management, 17(3), 217-227.

Rashid, Z. A. \& Bashir, M. S. (2004). Economic Impacts of Changing Tourist Profile in Malaysia: An Inter-Industrial Analysis. ASEAN Journal on Hospitality and Tourism, 3, 29-39.

Ruiz, A. L. (1985). Tourism and the Economy of Puerto Rico: An Input-Output Approach. Tourism Management, 6(1), 61-65.

Sadi, M., \& Bartels, F. (1997). The Rise of Malaysia' Tourism Industry. Cornell Hotel and Restaurant Administration Quarterly, 38 (5), 88-95.

Tohamy, S. \& Adrian, S. (2000). The Economic Impact of Tourism in Egypt. The Egyptian Center for Economic Studies, Working Paper $\quad$ No. 40.4 Available: http://bibemp2.us.es/turismo/turismonet1/economia\%20del\%20turismo/turismo\%20zonal/africa/ECONOMIC\%20IMP ACT\%20OF\%20TOURISM\%20IN\%20EGYPT.PDF (August 22, 2005)

The Economic Planning Unit. (EPU). (2001). Eighth Malaysia Plan 2001-2005. Putrajaya,: Prime Ministers Department.

The Economic Planning Unit (EPU). (2006). Ninth Malaysia Plan 2006-2010. Putrajaya,: Prime Ministers Department. UN. (1999). Handbook of Input- Output Table Compilation and Analysis. NY: UN.

Vilaplana, J., Pai, D. Y. \& Hushak, L. J. (1991). Supply Side Benefits of Fisheries: Estimation of Economic Impacts Using IMPLAN. In Paper Presented at the IMPLAN Workshop. Columbus, OH: The Ohio State University.

Wagner, J.E. (1997). Estimating the economic impacts of tourist. Annals of Tourism Research, 24, 592-608.

Wanhill, S. (1994). The Measurement of Tourist Income Multipliers. Tourism Management, 15(4), 281-283

Wong, P.P. (1986). Tourism Development and Resorts on the East Coast of Peninsular Malaysia. Singapore Journal of Tropical Geography, 7(2), 152-162.

Table 1. Average Tourism Multipliers; Output, Income, Employment, Value-added, and Import

\begin{tabular}{|c|c|c|c|c|c|c|c|}
\hline Tourism Sector & \multicolumn{5}{|c|}{ Normal Multipliers } & \multicolumn{3}{c|}{ Ratio Multipliers } \\
\hline & Direct & Indirect & Induced & Total & Type I & Type II & Rank \\
\hline & 1 & 2 & 3 & $(1+2+3)$ & $(1+2) / 1$ & $(1+2+3) / 1$ & \\
\hline Tourism Average: & & & & & & & \\
\hline Output & 0.216205 & 1.136366 & 0.066347 & 1.418918 & 6.255965 & 6.5628362 & \\
\hline Income & 0.273818 & 0.066867 & 0.013864 & 0.354549 & 1.244202 & 1.2948345 & \\
\hline Employment & 0.12503 & 0.039705 & 0.009252 & 0.173987 & 1.317564 & 1.391562 & \\
\hline Value-added & 0.385864 & 0.141296 & 0.03365 & 0.56081 & 1.366181 & 1.4533877 & \\
\hline Import & 0.158205 & 0.052267 & 0.009792 & 0.220264 & 1.330375 & 1.3922695 & \\
\hline
\end{tabular}

Source: Authors' calculation. 
Table 2. Output multipliers

\begin{tabular}{|c|c|c|c|c|c|c|c|c|}
\hline Tourism Sector & \multicolumn{5}{|c|}{ Normal Multipliers } & \multicolumn{3}{c|}{ Ratio Multipliers } \\
\hline & Direct & Indirect & Induced & Total & Rank & Type I & Type II & Rank \\
\hline & 1 & 2 & 3 & $(1+2+3)$ & & $(1+2) / 1$ & $(1+2+3) / 1$ & \\
\hline Output: & & & & & & & & \\
\hline Accommodation & 0.221319 & 1.167411 & 0.052769 & 1.441499 & 2 & 6.274789 & 6.5132185 & 4 \\
\hline Food \& Beverage & 0.427516 & 1.355483 & 0.040428 & 1.823427 & 1 & 4.170602 & 4.2651667 & 6 \\
\hline Tour \& Transport & 0.242699 & 1.106414 & 0.059392 & 1.408505 & 3 & 5.558791 & 5.8035056 & 5 \\
\hline Entertainment & 0.154864 & 1.078079 & 0.049475 & 1.282418 & 5 & 7.961457 & 8.2809304 & 3 \\
\hline Shopping & 0.104208 & 1.041693 & 0.054658 & 1.200559 & 6 & 10.99629 & 11.520795 & 1 \\
\hline Miscellaneous & 0.146621 & 1.069117 & 0.141362 & 1.3571 & 4 & 8.291704 & 9.2558365 & 2 \\
\hline
\end{tabular}

Source: Authors' Calculation

Note: Rank 1 and rank 2, in terms of normal and ratio multipliers, signify the relative significance of each of the six tourism sectors, where 1 is the most important and 6 is the least important correspondingly.

Table 3. Income multipliers

\begin{tabular}{|c|c|c|c|c|c|c|c|c|}
\hline Tourism Sector & \multicolumn{4}{|c|}{ Normal Multipliers } & \multicolumn{3}{c|}{ Ratio Multipliers } \\
\hline & Direct & Indirect & Induced & Total & Rank & Type I & Type II & Rank \\
& 1 & 2 & 3 & $(1+2+3)$ & & $(1+2) / 1$ & $(1+2+3) / 1$ & \\
\hline Income: & & & & & & & & \\
\hline Accommodation & 0.577679 & 0.069118 & 0.011026 & 0.657823 & 2 & 1.119648 & 1.1387345 & 5 \\
\hline Food \& Beverage & 0.153033 & 0.12425 & 0.008449 & 0.285732 & 3 & 1.811916 & 1.8671267 & 3 \\
\hline Tour \& Transport & 0.099546 & 0.075518 & 0.012411 & 0.187475 & 4 & 1.758624 & 1.8833002 & 2 \\
\hline Entertainment & 0.646926 & 0.06144 & 0.010339 & 0.718705 & 1 & 1.094972 & 1.110954 & 6 \\
\hline Shopping & 0.139137 & 0.031659 & 0.011422 & 0.182218 & 5 & 1.227538 & 1.3096301 & 4 \\
\hline Miscellaneous & 0.026586 & 0.039217 & 0.029539 & 0.095342 & 6 & 2.4751 & 3.5861732 & 1 \\
\hline
\end{tabular}

Source: Authors' Calculation

Note: Rank 1 and rank 2, in terms of normal and ratio multipliers, signify the relative significance of each of the six tourism sectors, where 1 is the most important and 6 is the least important correspondingly. 
Table 4. Employment multiplier

\begin{tabular}{|c|c|c|c|c|c|c|c|c|}
\hline Tourism Sector & \multicolumn{5}{|c|}{ Normal Multipliers } & \multicolumn{3}{c|}{ Ratio Multipliers } \\
\hline & Direct & Indirect & Induced & Total & Rank & Type I & Type II & Rank \\
\hline & 1 & 2 & 3 & $(1+2+3)$ & & $(1+2) / 1$ & $(1+2+3) / 1$ & \\
\hline Employment: & & & & & & & & \\
\hline Accommodation & 0.127657 & 0.039962 & 0.007357 & 0.174976 & 3 & 1.313042 & 1.370673 & 4 \\
\hline Food \& Beverage & 0.053314 & 0.059515 & 0.005637 & 0.118466 & 6 & 2.116311 & 2.222043 & 1 \\
\hline Tour \& Transport & 0.150479 & 0.05122 & 0.008281 & 0.20998 & 1 & 1.34038 & 1.3954107 & 3 \\
\hline Entertainment & 0.129114 & 0.033826 & 0.006898 & 0.169838 & 4 & 1.261986 & 1.3154112 & 5 \\
\hline Shopping & 0.171271 & 0.022408 & 0.007631 & 0.20131 & 2 & 1.130834 & 1.1753887 & 6 \\
\hline Miscellaneous & 0.118344 & 0.031298 & 0.019711 & 0.169353 & 5 & 1.264466 & 1.4310231 & 2 \\
\hline
\end{tabular}

Source: Authors' Calculation

Note: Rank 1 and rank 2, in terms of normal and ratio multipliers, signify the relative significance of each of the six tourism sectors, where 1 is the most important and 6 is the least important correspondingly.

Table 5. Value-added multipliers

\begin{tabular}{|c|c|c|c|c|c|c|c|c|}
\hline Tourism Sector & \multicolumn{5}{|c|}{ Normal Multipliers } & \multicolumn{3}{|c|}{ Ratio Multipliers } \\
\hline & Direct & Indirect & Induced & Total & Rank & Type I & Type II & Rank \\
\hline & 1 & 2 & 3 & $(1+2+3)$ & & $(1+2) / 1$ & $(1+2+3) / 1$ & \\
\hline Value-added & & & & & & & & \\
\hline Accommodation & 0.354958 & 0.14878 & 0.026763 & 0.530501 & 4 & 1.419148 & 1.4945458 & 4 \\
\hline Food \& Beverage & 0.222055 & 0.231509 & 0.020504 & 0.474068 & 5 & 2.042575 & 2.1349125 & 2 \\
\hline Tour \& Transport & 0.347905 & 0.15729 & 0.030122 & 0.535317 & 3 & 1.452106 & 1.5386873 & 3 \\
\hline Entertainment & 0.591758 & 0.124493 & 0.025093 & 0.741344 & 2 & 1.210378 & 1.2527824 & 5 \\
\hline Shopping & 0.668509 & 0.081217 & 0.027722 & 0.777448 & 1 & 1.12149 & 1.1629582 & 6 \\
\hline Miscellaneous & 0.129999 & 0.104488 & 0.071695 & 0.306182 & 6 & 1.80376 & 2.3552643 & 1 \\
\hline
\end{tabular}

Source: Authors' Calculation

Note: Rank 1 and rank 2, in terms of normal and ratio multipliers, signify the relative significance of each of the six tourism sectors, where 1 is the most important and 6 is the least important correspondingly. 
Table 6. Import multipliers

\begin{tabular}{|c|c|c|c|c|c|c|c|c|}
\hline Tourism Sector & \multicolumn{5}{|c|}{ Normal Multipliers } & \multicolumn{3}{c|}{ Ratio Multipliers } \\
\hline & Direct & Indirect & Induced & Total & Rank & Type I & Type II & Rank \\
\hline & 1 & 2 & 3 & $(1+2+3)$ & & $(1+2) / 1$ & $(1+2+3) / 1$ & \\
\hline Import: & & & & & & & & \\
\hline Accommodation & 0.192223 & 0.054504 & 0.007788 & 0.254515 & 2 & 1.283546 & 1.3240611 & 3 \\
\hline Food \& Beverage & 0.125245 & 0.103563 & 0.005967 & 0.234775 & 4 & 1.826883 & 1.8745259 & 1 \\
\hline Tour \& Transport & 0.252088 & 0.066525 & 0.008765 & 0.327378 & 1 & 1.263896 & 1.2986655 & 4 \\
\hline Entertainment & 0.055624 & 0.032711 & 0.007301 & 0.095636 & 6 & 1.588073 & 1.7193298 & 2 \\
\hline Shopping & 0.131783 & 0.021976 & 0.008067 & 0.161826 & 5 & 1.166759 & 1.2279733 & 6 \\
\hline Miscellaneous & 0.192267 & 0.034321 & 0.020863 & 0.247451 & 3 & 1.178507 & 1.2870175 & 5 \\
\hline
\end{tabular}

Source: Authors' Calculation

Note: Rank 1 and rank 2, in terms of normal and ratio multipliers, signify the relative significance of each of the six tourism sectors, where 1 is the most important and 6 is the least important correspondingly.

Million (RM)

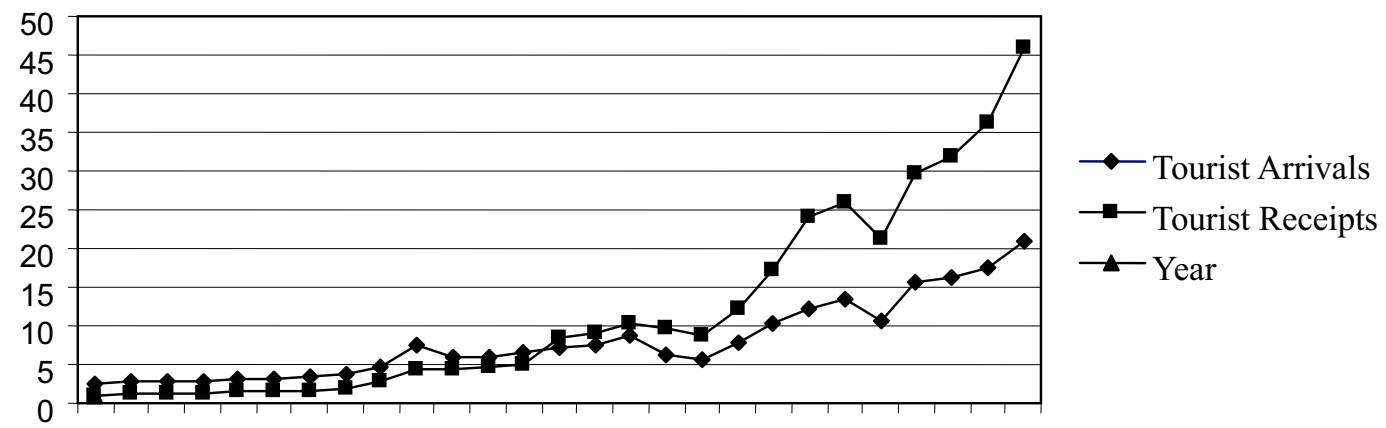

19811983198519871989199119931995199719992001200320052007

Year

Figure 1. International Tourist Arrival and Receipts

Source: Annual Tourism Statistical Report several years, MTPB. 